\title{
Suomalaisen kapitalismin tutkimus Sakari Hännisen, Antti Kasvion, Pekka Kososen ja Kari Toikan haastattelu
}

Tämän vuoden lokakuussa ilmestyy Love Kirjojen kustantamana tärkeä kirja "'Suomalainen kapitalismi". Se liittyy vuonna 1972 käynnistyneen Valtiomonopolistinen kapitalismi Suomessa -projektin tuloksiin, samalla kun kirjasta viime vaiheessa on vastannut kirjoittajaryhmä, johon neljä haastateltavaamme ovat kuuluneet.

Kyselimme tekijöiden arvioita kirjasta, sen synnystä ja yleensä kapitalismitutkimuksen tilasta. Seuraavassa numerossa ovat vuorossa kriitikot. - Toimitus.

\section{Miten luonnehtisitte lyhyesti kirjaa Suomalainen} kapitalismi? Mikä on sen tavoite?

Pekka Kosonen: Kirja pyrkii yhtenäiseen ja samalla pitkälle erikoispiirteiden mukaan jäsennettyyn esitykseen suomalaisesta kapitalismista. Kyse on siis painotetusti konkreettisesta tutkimuksesta; kirja ei kuitenkaan ole poliittinen arvio tai poliittinen ohjelma, vaan nimenomaan tutkimusta ja analyysia, yritys paljastaa suomalaisen kapitalismin keskeiset liikevoimat ja ristiriidat. Toisaalta sen taustana on varsin laaja teoreettinen keskustelu, jota marxilaiset yhteiskuntatieteilijät ovat 70-luvulla Suomessakin käyneet. Haluan korostaa myös sitä, että vaikka tutkimuksemme rakentuu monille aiemmin esitetyille analyyseille ja projektin työlle, kirjoittajaryhmä — ja ehkä minä vastaavana kirjoittajana eniten vastaa tekstistä itse. Esitys on siis eräs näkökulma suomalaisen kapitalismin ongelmiin, ja toivomme siitä keskustelua ja kritiikkiä.

Voiko tätä analyysia tiivistää jotenkin? Millaisen kuvan kirja antaa esimerkiksi 70-luvun loppupuolen kriisistä ja yleensä suomalaisen kapitalismin erikoispiirteistä?

Pekka Kosonen: Näinkin laajaa tekstiä on vaikea tiivistää muutamaan lauseeseen, kyllä kiinnostuneen täytyy lukea kirja. Joitakin keskeisiä ajatuksia voi tietenkin yrittää poimia.
Tutkimme kapitalistien suhteiden leviämistä, kapitalisoitumiskehitystä, Suomessa. Ajatuksena on nähdä vuorovaikutusprosessi voiton tuotannon ja rakenteellisten tekijöiden välillä: arvonlisäys- eli voittomotiivi on liikkeellepaneva voima, mutta se muokkaa tuotannon rakenteellisia tekijöitä, jotka puolestaan ovat voiton tuotannon perustana jatkossa. Näin on muovautunut metsäteollisuuden keskeinen asema taloudessa, maatalouden suhteellinen pysyvyys metsäteollisuuteen liittyen, tuotannonalarakenteen suhteellinen yksipuolisuus ja erityisesti länsikaupan vinoutuneisuus, tähän kytkeytynyt pyrkimys pärjätä kansainvälisessä kilpailussa pitämällä palkkatasoa alhaisena, teollisuuden rakenteeseen liittyvä tarve suuriin investointeihin ja näitä investointeja tukenut talouspolitiikka.

Erityisesti olemme olleet kiinnostuneita 60 - ja 70-lukujen suuresta yhteiskunnallisesta rakennemuutoksesta. Pääoman kasaantuminen ja talouspolitiikka loivat varsin suotuisat ehdot pääoman arvonlisäykselle 60-luvulla ja 70-luvun alkupuolella. Tuotanto kasvoi jatkuvasti, ja sitä sopeutettiin yhä avoimempaan kansainväliseen kilpailuun - toteutui voimakas ja hallitsematon rakennemuutos. Työvoimaa vapautettiin nopeaan tahtiin maa- ja metsätaloudesta, ja kansainväliseen kilpailuun sopeutumista edisti valtiomonopolistisen taloussääntelyn selvä aktivointi: yritysten rahoitusmahdollisuuksien parantaminen ja tulopolitiikan käyttöönotto palkkakustannusten hillitsemiseksi. Tämä taasen edellytti muutoksia poliittisessa järjestelmässä eli siirtymistä vuodesta 1966 alkaen integrointipolitiikan ja reformistisen hallitustyypin perustalle. Suuryritysten kasaamista tukevan talouspolitiikan eräänä tuloksena oli sitten investointiasteen kasvu vuosina -74 ja -75 kansainvälisestikin verraten huippukorkeaksi, mikä merkitsi pääoman liikakasaantumista.

Taloudellista kriisiä 70-luvun jälkipuoliskolla on tarkasteltu tältä edeltävän kehityksen analyysin pohjalta. Pääoman liikakasaantuminen kärjistyi muiden kapitalististen maiden suhdannelamaan 
liittyen vuonna 1975. Meillä ongelmia lisäsi talouspolitiikan varsin kireä, kysyntää supistava linja, millä on pidetty yllä suurtyöttömyyttä. Mutta samalla Suomen tuotannon rakenteelliset ongelmat, esimerkiksi länsikaupan erikoistumisrakenne, ovat vaikeuttaneet ulospääsyä kriisistä ja lamasta. Näyttää siltä, että työllistämisen vaikeudet ovat kasvaneet, eikä edes tuotannon kohtuullinen kasvu auta työllistämään kaikkia työttömiä. Siten tutkimuksemme ei ole sidoksissa vain määrättyyn suhdannevaiheeseen, vaan pyrkii kiteyttämään tätä yleisempiä ongelmia. Pyrimme myös välttämään sitä, että taloudellisesta kriisistä vedetään suoria päätelmiă poliittisen tai ideologisen kriisin olemassaolosta. Tietynlaisesta tyytymättömyyden kasvusta huolimatta ei mielestämme voi puhua poliittisesta kriisistä Suomessa.

Sakari Hänninen ja Antti Kasvio: mihin uudet näkemykset luvuissa pääoman uusintamisesta ja työvoiman uusintamisesta perustuvat?

Sakari Hänninen: Ei voi oikeastaan puhua uudenlaisesta näkökulmasta itse pääoman kasaantumisanalyysissa, sillä mistään uudesta tutkimusorientaatiosta ei ole kysymys. Suomalainen kapitalismi -kirjassa jatketaan sitä perinnettä, joka alkoi jo Valtiomonopolistinen kapitalismi Suomessa -projektin alkuvaiheessa ja kulminoitui mallikkaasti TANDEMin loppuraportissa. Kirjassa on kyllä pyritty kiertämään ja ratkomaan niitä rajausongelmia, jotka ovat aiemmin liittyneet arvonlisäysehtojen ja tuotannollis-teknisten ehtojen epäanalyyttiseen yhteenkietoutumiseen ja samalla on pyritty välttämään sellaisten vaikeasti pääteltävien synteettisten indikaattorien kuten pääomakertoimen käyttöä. Uudesta näkökulmasta ja uusista näkemyksistä voi ehkä puhua tässä rajatussa mielessä.

Näkökulman päälinjana on, että myös konkreettisessa eikä vain kapitalismin yleisessä analyysissa on pidettävä kiinni työprosessin ja arvonlisäysprosessin sekä niitä kuvaavien indikaattorien erosta ja erityisyydestä. Myös konkreettis- yleisessä tarkastelussa uusintamistyypin käsite on puolitettava kahtia työn kaksinaisluonnetta vastaavasti. Tuloksena ovat työprosessia vastaavan tuotantomuodon ja arvonlisäysprosessia vastaavan arvonlisäysmuodon käsitteet välityskategorioina, jotka ovat käypiä kapitalismin kehityslakien erityisten toteutumismuotojen tasolla, siis konkreettisemmalla tasolla kuin "Pääoman" kolmannen kirjan yleiset toteutumismuodot, mutta kuitenkin kapitalismin historiallis-reaalisten ilmenemismuotojen pintaa yleisemmällä tarkastelutasolla.

Tuotantomuoto vastaa tuotantovoimien konkreettis-erityistä toteutumismuotoa kun taas arvonlisäysmuoto vastaa tuotantosuhteiden konkreettiserityistä toteutumismuotoa viitaten konkreettisiin voiton tuottamisen ehtoihin. Tämä erottelu ei poista vaan tukee asetettua konkreettisen tutkimuksen metodologista periaatetta, että tehtävänä on "Pääoman" yleisten lakien uusien toteutumismuotojen tunnistaminen ja konkreettinen erittely. Niinpä on tarkasteltu erikseen suomalaisen tuotantomuodon erikoispiirteitä erottamalla yhdeksän ominaislaadun kompleksia, joita on pyritty mahdollisimman, joskaan ei varmaan riittävän, konkreettisesti hahmottamaan jopa esimerkein. Vastaavasti suomalaisen pääoman arvonlisäysmuotoa on pyritty tarkastelemaan ensinnäkin systemaattisesti pääomarentabiliteetti-indikaattorin avulla ja toiseksi hajottamalla ja analysoimalla tähän vaikuttavia osatekijöitä.

Tarkastelun suurimpia puutteita on se, että vieläkään ei ole kyetty riittävän yksityiskohtaisesti erittelemään suomalaisten vientituotteiden hinnanmuodostusta maailmanmarkkinoilla ja työvoiman hintakehitystä sekä niiden vaikutuksia. Kannattaa myös mainita, että ennen tuotanto- ja arvonlisäysmuodon analyysia on tutkittu ylipäänsă taloudellisen kasvun ripeyttă ja talouden suurten lohkojen muutosta Suomessa ja ennen on myös esitetty tavallaan perinteinen kasaantumisanalyysi, jolla juuri perustellaan uuden näkökulman tarve. Tulokset eivät ole lopullisia, mutta 
uskoakseni astinlauta eteenpäin. Kuriositeetin vuoksi voi mainita, ettei suomalaisen pääoman arvonlisäysehtoja tunnu niinkään kuvastavan voiton suhdeluvun lasku kuin pääomarentabiliteetin kasvu ainakin 60-luvulla ja 70-luvun alkupuolella.

Antti Kasvio: Valtiota ja työvoiman uusintamista koskevan luvun osalta pidän tärkeimpänä sitä, että ei ole rajoituttu ainoastaan kuvailemaan työväestön asemassa ja elinehdoissa toisen maailmansodan jälkeen tapahtuneita muutoksia, vaan on pyritty muodostamaan kokonaiskuvaa siitä, millä tavoin työväestön elinehtojen kehittyminen Suomessa on kytkeytynyt pääoman arvonlisäysehtojen ja kasautumisprosessin liikkeeseen. Tähän liittyy myös työvoiman uusintamisehtojen tarkastelutapa kirjassa: edeltävän pääoman uusintamisen erittelyn pohjalta analysoidaan työvoiman asemaa kasautumisprosessissa ja kapitalistisen väestölain liikkeen erityispiirteitä suomalaisessa kapitalismissa. Sitten edetään tutkimaan lähemmin työmarkkinoiden toimintaa ja työttömyyttä, työläisten asemaa kapitalistisessa tuotantoprosessissa, palkkoja ja tulonjakoa, yksilöllistä ja kollektiivista kulutusta sekä lopuksi kasautumiskriisin vaikutuksia työvoiman uusintamisehtojen kehittymiseen 1970-luvun Suomessa.

On toki todettava, että tässä kirjassa työvoiman uusintamisehtojen tarkastelu jää vielä monelta osin eräänlaiseksi tutkimuskentän jäsennykseksi kypsän kokonaiskuvan sijasta. Ehkä joissakin osissa kehittely on saatu vietyä muita osia pidemmälle - mainittakoon kollektiivisen kulutuksen eri muotojen erittely - mutta toisaalta joidenkin asioiden käsittely on jäänyt enemmän tai vähemmän kaavamaiseksi yleispiirteiden esittelyksi. Itse olisin toivonut, että kirjassa olisi ollut mahdollista toisaalta eritellä syvällisemmin työväenliikkeen ja työväenluokan käymän toimeentulokamppailun vaikutuksia työvoiman ja työväestön uusintamisehtojen muotoutumiseen sekä 1970-luvun puolivälin talous- pulan jälkeisen rationalisointiaallon vaikutuksia työvoiman uusintamisristiriitojen syvenemiseen. Tähän liittyy hyvin monta työväenliikkeen kannalta kipeää ja ajankohtaista ongelmaa: ei ainoastaan joukkotyöttömyyden kasvu, vaan myös uuden tekniikan vaikutukset työn sisältöön, työvoiman dekvalifikaatio, työn voimaperäistyminen ja työvoiman liiallinen kuluminen.

Kari Toikka, olet aiemmin jo Tiede ja edistyksessä (4/78) puuttunut TANDEMin hallitsemistapa-analyysin ongelmiin. Mikä nyt Suomalainen kapitalismi -kirjan suhde on TANDEMiin?

Kari Toikka: Politiikan tutkimuksen osalta voitaneen sanoa, että kirjat eivät korvaa toisiaan vaan edellyttävät ja täydentävät toisiaan. Yhdessä luettuna niissä lienee Suomen poliittisen järjestelmän marxilaisen kokonaiskäsityksen jonkinlainen välitase. Tämä johtuu siitä, että "Demokratian rajat ja rakenteet" -kirjassa politiikan analyysiin on varattu enemmän tilaa ja se on myöskin empiirisesti laajempaa. Toisaalta Suomalainen kapitalismi -kirjassa on siihen nähden tietty kriittinen teoreettinen jännite, joka mielestäni osoittaa suuntaa eräiden TANDEMin ongelmien ratkaisülle.

Kyse on ennen muuta poliittisen hallitsemistavan käsitteestä. TANDEMilla "suomalainen hallitsemistapa" tarkoittaa lähinnä porvarillisen valtion ja poliittisen järjestelmän suomalaiskansallista toteutumismuotoa. Vastaavasti "tulopoliittinen hallitsemistapa" tarkoittaa tämän poliittisen järjestelmän nykyistä valtiomonopolistista muotoa suomalaisittain. Tämä merkitsee hallitsemistavan aika voimakasta palauttamista taloudellisiin määreisiinsä, Suomen taloudelliseen ja sosiaaliseen rakenteeseen. Tästä seuraa hallitsemistavan pysyvyyden korostuminen jännittävällä, lähes aavemaisella tavalla. Tämä on minusta eräs TANDEMin parhaita oivalluksia kunhan nähdään, että kyse on poliittisen järjestelmän rakennepiirteistä eikä varsinaisesti hallitsemistavasta. Nyt jää ehkä liian vähälle käsitte- 
lylle se erityinen tapa - poliittisen vallan prosessi, luokkataistelu, sen voimasuhteen kehitys jonka kautta ja jonka tuloksena poliittisen järjestelmän talous- ja sosiaalirakenteesta näennäisen välittömästi määräytyvă poliittisen järjestelmän pysyvyys on vasta muodostunut.

"Suomalaisessa kapitalismissa" pyritään korostamaan juuri tämän poliittisen prosessin ominaislaatua, poliittisen vallan sisäistä ristiriitaa, voimasuhdetta, jota ilmaisee erityisesti työväenluokan vallankumouksellisen puolueen kulloinenkin asema. Tällöin käy mahdolliseksi ymmärtää, että vuonna 1944 ei tapahdu vain TANDEMin esittämä poliittisen järjestelmän vakiintuminen 1930-luvulla muodostuneelle pohjalle, vaan pikemminkin laadullinen muutos porvariston poliittisessa vallassa, siis hallitsemistavan vaihdos. Samaten hallitsemistavan kehityksessä vuoden 1966 jälkeen ei ole kysymys vain "perinteisen hallitsemistavan" kertautumisesta uudessa muodossa vaan pikemminkin laadullisesta muutoksesta porvariston ja työväenluokan valtasuhteessa hallitsemistavan sisällä - tätä pyritään esittämään hallitustyypin muutoksen kautta.

Vasta poliittisen muodon ominaislaadun, poliittisen vallan sisäisen ristiriidan huomioonottaminen tekee mielestäni mahdolliseksi ymmärtää tähän ristiriitaan perustuvien, mutta samalla sen ja politiikan kapitalistisen muodon ylittävien reaalisten demokraattisten ja vallankumouksellisten tendenssien mahdollisuus. Luulisin että se tietty skeptisyys, jota "Demokratian rajat ja rakenteet" osoittaa loppuarviossaan demokraattisen liikkeen näkymistä saattaa olla yhteydessä sen politiikka-käsityksen edellä arvioituihin ominaisuuksiin. Itse pidän mahdollisena päästä poliittisen vallan tarkemman erittelyn kautta vähemmän skeptisiin näkymiin.

Pekka Kosonen mainitsi edellä, että kirjan valmistelun taustana on laaja teoreettinen keskustelu. Mikä tämä keskustelu tarkemmin ottaen on? Miten se suhtautuu kansainvälisiin traditioihin?
Pekka Kosonen: Alussa, 70-luvun alkupuolella, perustana projektissa olivat eräăt eri kapitalistisia maita käsittelevät erittelyt, jotka tunnetaan valtiomonopolistisen kapitalismin tutkimuksena. Näistä eräänlainen yleisteos on lähiaikoina kuulemma suomeksikin ilmestyvä "Nykyajan monopolikapitalismin poliittinen taloustiede", sen lisäksi oli tutkimuksia Saksan liittotasavallan ja Ranskan kapitalismista. Tässä tutkimustraditiossa korostetaan kapitalismin muutoksia: monopolisoitumista, valtion roolin kasvua ja erilaisia teknisen kehityksen vaiheita. Tällaista muutosten huomioonottoa pidimme tärkeänä.

Toisaalta halusimme varsin pian analysoida entistä syvällisemmin myös kapitalismin yleisiä lakeja ja perusominaisuuksia. Nämähän on esitetty Marxin poliittisen taloustieteen kritiikissä, ennen muuta "Pääomassa", jossa tulkintamme mukaan on kyse juuri kapitalistisen yhteiskunnan sisäisen organisaation esityksestä. Tästä näkökulmasta korostuvat tavara- ja rahasuhteiden sekä pääomasuhteen leviämisen analyysi. Näitä yhteiskuntamuodon tutkimisen ongelmia on laiminlyöty myös marxilaisessa tutkimuksessa, mutta kysymys aktualisoitui laajan poliittisen taloustieteen kritiikkiä koskevan tulkintakirjallisuuden myötä, jota monissa maissa mutta ehkä erityisesti Saksan liittotasavallassa on 70-luvulla julkaistu.

Kaiken kaikkiaan olemme kehitelleet teoreettista ja metodologista perustaa eri lähteiden pohjalta ja pyrkineet oman näkemyksemme kiteyttämiseen. Olemme liittäneet poliittisen taloustieteen kritiikin määrityksiin kapitalismin vaiheiden tutkimisen, kapitalismin jatkokehityksen käsitteellistämisen. Samalla työn edetessä on pohdittu yhä enemmän konkreettisen tutkimuksen metodologiaa, koska varsinainen tavoite on ollut suomalaisen kapitalismin erittely. Itse asiassa näen monet valtiomonopolistisen kapitalismin tutkimustradition käsitteet lähinnä tälle tasolle kuuluvina: ei niinkään yleisteoreettisinä käsitteinä kuin konkreettiseen tutkimukseen liittyvinä välineinä. 
Tällaisesta tulkinnasta seuraa, että valtiomonopolistisen kapitalismin teoriasta ei vahvassa mielessä ehkä voi puhuakaan. Tämän tutkimuksen käsitteet voivat kuitenkin olla tarpeellisia apuvälineitä konkreettisessa tutkimuksessa, esimerkiksi periodisoitaessa kehitystä tai vertailtaessa eri maiden asemaa. Olemme kuitenkin kehitelleet myös omaa konkreettisen tutkimuksen metodologiaa, jossa on suoritettu kriittistä rajanvetoa pyrkimyksiin todistaa empiirisellä aineistoilla yleisiä lakeja tai lainmukaisuuksia oikeaksi. Tätä parempana pidämme kapitalismin lakien uusien toteutumismuotojen erittelyä kunkin maan erikoispiirteen huomioonottaen.

Mutta yleisesti teoreettisesta keskustelusta voi sanoa, että vaikka itse kirjan tekstissä yleistä teoreettista analyysia on enää vähän, koska lähtökohdat on pyritty suodattamaan Suomea koskevaan aineistoon, jatkuva ja kriittinen teoreettinen keskustelu on tarpeen, aina peruslähtökohtia myöten.

Kari Toikka: Kirjan politiikkaa käsittelevien osien kohdalla tilanne poikkeaa jossain määrin taloudellisesta analyysista, jossa teoreettinen perusta riippumatta edellä mainitusta itsenäisestä kehittelystä - on voitu suuremmassa määrin ottaa 'valmiina tavarana'. Se suppea politiikan teoreettinen käsittely, mikä kirjaan on mahtunut jää parhaimmillaankin viitteelliseksi, tulosten esittelyksi prosessissa joka ei ole näkyvissä ja joka ylipäänsä vasta on hahmottumassa.

Erityisesti marxilais-leniniläisen yleisen valtioja oikeusteorian ja poliittisen sosiologian nykykeskustelussa sosialistisissa maissa, johon kirjan politiikkaosa lähinnä perustuu, korostuu toisaalta keskeisten poliittiseen valtaan liittyvien käsitteiden keskustelunalaisuus. Näiden kysymysten suhteen myőskään ns. pääomaloogisella valtiokeskustelulla ei ole ollut tavattoman paljon annettavana. Sen vahva puoli on porvarillisen poliittisen muodon ja taloudellisen muodon yleisen keskinäissuhteen erittelyssä. Heikkoudeksi tämä muuttuu muodostuessaan esteeksi talouden ja politiikan keskinäissuhteen historiallisen kehityksen käsittämiselle puhumattakaan kyvylle käsittää poliittinen subjekti realistisesti, taloudellisiin muotomääreisiinsä, luonnenaamioon redusoimattomana, ne ylittävänä. Kysymystä poliittisen vallan omalakisuuden ja sen spesifin sisäisen ristiriidan käsittämisestä ei voida asettaa poliittisen taloustieteen rajoissa, vaan edellytyksenä on $\mathrm{mm}$. poliittisen psykologian integroiminen politiikan teoriaan. Kyse on toisin sanoen yhteiskunnallisesta tietoisuudesta, yhteiskunnallisen ja yksilöllisen tietoisuuden suhteesta, persoonallisuudesta jne.

Politiikan tutkimuksessa kannattaa siis puhua enemmänkin mahdollisuuksista ja kehitysnäkymistä. Teoreettinen työ ja keskustelu tulevat vilkastumaan. Niiden hedelmällisyys riippuu aika lailla siitä, missä määrin ne kytkeytyvät Suomen poliittisen järjestelmän empiiriseen analyysiin ja poliittisen käytännön ajankohtaisten ongelmien ratkaisuun. Esimerkiksi voimasuhteen käsite on mielestäni eräs politiikan erityislaadun teoreettinen kiteytymä. Samalla kysymys voimasuhteesta liittyy mitä läheisimmin kommunistisen puolueen taktiikan ajankohtaisiin ongelmiin, kysymykseen siitä, mikä on nykyisen poliittisen tilanteen luonne, mitä mahdollisuuksia se tarjoaa ja millaisia vaatimuksia se asettaa demokraattiselle kehitykselle. Käsitykset tästä ovat tunnetusti melko heterogeenisia, millä on tietty yhteytensä teoreettisen ja empiirisen tutkimuksen kehitysvaiheeseen.

Tähän teoreettiseen keskusteluun liittyen: millaisia keskeisiä ongelmia viime aikoina on ollut esillä?

Pekka Kosonen: Eräs mielestäni sittenkin aika yleisten analyysien varaan jäänyt kysymys on niiden syiden pohdinta, jotka liittyvät valtion kasvavaan väliintuloon yhteiskunnalliseen uusintamiseen. Usein valtion väliintuloa on selitelty suoraan pääoman vaatimuksista käsin, jolloin helposti päädytään reduktionismiin. Kirjassa 
Suomalainen kapitalismi asia on yritetty nähdä vivahteekkaammin, niin että pääoman uusintamisen ristiriidat kyllä ovat analyysin yleisenä perustana, mutta kyse on myös työläisten tarpeista - esimerkiksi kollektiivisen kulutuksen laajeneminen - ja näiden huomioonottamiseen liittyvistä välttämättömyyksistä. Tällöin tärkeää on tutkia sekä pääoman että työläisten vaatimusten monimutkaista välittymistä valtion toimiksi eritasoisen poliittisen toiminnan, reformien ja reformismin jne. kautta. Myös valtiomonopolistisen sääntelyn käsite on usein jäänyt tavallaan ryväskäsitteeksi, jolloin sekä suuryritysten suora tukeminen että eläkepolitiikka ovat samaa sääntelyä. Analyysissa tarvitaan varsin eriytynyttä otetta.

Toisena kysymyksenä voi mainita kriisianalyysin. Yleisesti ottaen sen perustana voi nähdä poliittisen taloustieteen kritiikin esityksen pääoman liikakasaantumisesta ja arvonmenetyksestä sekä syklisistä kriiseistä. Tämän lisäksi on tutkittava niitä uusia kapitalismin historialliseen muuttumiseen liittyviä piirteitä, jotka vaikuttavat siihen, että liikakasaantuminen ei ole vain suhdanneilmiö vaan paljolti myös krooninen luonteeltaan. Näissä molemmissa kysymyksissä on vielä paljon selvittämistä: liian usein tyydytään vain viittaamaan kapitalismin perusristiriitoihin kriisiselityksenä.

Sakari Hänninen: Teoreettisen keskustelun painopisteen suhteen voin yhtyä Toikan korostamaan politiikan jäsentämisen tarpeeseen. Perustelisin tätä tarvetta hieman toisesta perspektiivistä. Nähdäkseni marxilainen valtioteoria on vasta tulemisensa prosessissa eikä ole olemassa, missään traditiossa, mitään Marxilaista Valtioteoriaa. Tarvitaan koko joukko niin teoreettista kuin konkreettista politiikan tutkimusta teorianmuodostuksen perustaksi. Toisaalta tuotettu käsiteviidakko voi jopa vaikeuttaa asioiden hahmottamista, toisaalta monen politiikan osa-alueen jäsentämiseen tarvittavat teoreettisesti perustellut käsitteet puuttuvat tai sitten ovat puhtaasti geneerisiä abstrak- tioita, joiden genesis jää osoittamatta. Suomalainen kapitalismi -kirjaan sisältyy nähdäkseni myös problemaattisia vaikkakin tällä teorian kehitystasolla varsin käypiä käsitteitä. Eräät käsitteet kuten valtiollinen sääntely ovat kovin ryväsmäisiä ja aggregatiivisia ja jäävät analyyttiselta erottelukyvyltään heikoiksi. On vielä tavallaan negatiivisia apukäsitteitä kuten valtion suhteellinen itsenäisyys, joka tulevaisuudessa tulisi korvata positiivisilla määrityksillä. Voi myös olla hyviä deskriptiivisiä kategorioita, jotka silti eivät ole selittäviä — näihin kuuluu mielestäni voimasuhteen käsite. Osin on jopa keinotekoisia, fiktiivisiä ajatuskonstruktioita kuten valtion voima, joka olisi palautettava reaalisesti olemassaoleviin tekijöihinsä. Tässä tilanteessa olisi välttämätöntä tehostaa keskustelua eri marxilaisten politiikan tutkimuksen traditioiden välillä. Onneksi tämä keskustelu on Suomessa jo käynnissä. Sen yhteyteen olisi hedelmällistä kytkeä myös politologian erittely ja ideologiakritiikki.

Antti Kasvio: Omasta puolestani näkisin jatkokehittelyä kaipaavana teoreettis-metodologisena ongelmana suomalaisen kapitalismin erittelyssä analyysin historiallistamisen, nykykapitalismin lainalaisuuksien liikkeen näkemisen historiallisena prosessina. Nyt kirjassa on joukko erilaisia historiikkeja, mutta ei vielä oikein historiaa.

Toisena tärkeänä ongelmana on työväenliikkeen ja työväen joukkojärjestöjen tutkimisen kohottaminen teoreettiselle tasolle. Kirjassamme työväenluokka ja työväenliike esiintyvät pikemminkin eräänlaisina ulkoisina tekijöinä kuin analyysin sisäisenä, elimellisenä momenttina. Sellaisia seikkoja kuin reformismia, suomalaisen työväenliikkeen aatteellista kehitystä, sen ohjelmallisia tavoitteita jne. ei ole kirjassa kyetty riittävästi sulauttamaan osaksi suomalaisen kapitalismin kokonaiskuvaa. 
Tällaisessa tutkimuksessa nousee kai aina ongelmaksi teoreettisen pyörittelyn ja empiirisen aineiston käsittelyn välinen kuilu. Miten olette pohtineet tätä ongelmaa?

Sakari Hänninen: Totesin jo edellä, että olemme omaksuneet täsmällisen konkreettisen tutkimuksen metodologisen periaatteen: tavoitteena on ollut kapitalismin lakien toteutumismuotojen tunnistaminen ja konkreettinen erittely Suomen erikoisolosuhteet huomioonottaen. Kun on painotettu konkreettisen ja teoreettisen tutkimuksen välitysongelmaa, välitysmuotojen ja välityskategorioiden kehittämistä, niin samalla on pyritty välttämään toisaalta teoriatonta tai luokittelevaa hapuilua empiriassa ja toisaalta subsumptioloogista teorian madaltamista ideaalityyppiseksi tulkinta- ja todistuskaavioksi. Omaksuttu päämäärä ja sen saama konkreettinen tutkimuksellinen hahmo on kiteytynyt niin itse teoreettisen ja konkreettisen tutkimustyön kuluessa kuin niiden kriittisten arvioiden välityksellä, joita on kohdistettu eräisiin muihin konkreettisen tutkimuksen tapoihin kuten nk. reaalianalyysiin.

Suomessa on kuitenkin tuskin nimeksi keskusteltu näistă lähes kaikkia marxilaisia tutkijoita koskevista ydinkysymyksistä - voisi sanoa kysymyksistä, jotka mittaavat kunkin tieteellisen tradition tieteellistä kypsyyttä. Tässä yhteydessä olisikin oikea paikka haastaa niin filosofit, historioitsijat kuin yhteiskuntatieteilijät pyöreiden pöytien keskusteluun konkreettisen tutkimuksen metodologiasta ja ylipäänsä teoreettisen ja konkreettisen tutkimuksen välityksestä. Väittäisin, että Suomalainen kapitalismi -kirjassa - kuten jo TANDEM- ja DETA-tutkimuksissa - on käytännön tilassa runsaasti keskustelun aineksia. Väittäisin tässä kysymyksessä vielä muutakin, joka liittyy aivan konkreettisesti tutkimuksemme sisältöön. Mielestäni marxilaisen konkreettisen tutkimuksen tulee olennaisessa mielessä olla sekä historiallista että vertailevaa. Suomalainen kapitalismi -kirjan osalta tarkastelun historiallisuuden vaatimus on suhteellisen hyvin toteutettu sen kui- tenkaan missään kohdassa varsinaisesti olematta historiantutkimusta. Sen sijaan vertailevan tutkimuksen vaateet on kirjassa jouduttu sivuuttamaan tuskastuttavan pikaisesti. Tähän on monta syytä, joista vähäisin ei suinkaan ole kansainvälisesti vertailukelpoisten tilastojen ja muun aineiston saatavuus. Lisäksi kirjamme on systemaattista ja syntetisoivaa tutkimusta, joka pitkälle rakentuu jo olemassaolevan erillistutkimuksen perustalle. Kun Suomen osalta useimmilta yhteiskunnan osa-alueilta vielä puuttuvat perusteelliset selvitykset, ollaan kohdittain ajauduttu tilanteisiin, joissa on pakko tehdä sangen "ohuita yleistyksiä". Tulevaisuutta ajatellen marxilaisen konkreettisen tutkimuksen painopistettä olisikin kohdistettava tällaiseen kohdespesifiin ja ongelmakeskeiseen perustyöhön.

Jos vielä pikaisesti arvioisin tutkimustamme kokonaisuutena olisi jälkiviisaasti jaettava niin plussia kuin miinuksia. Tutkimuskohdetta on pohdittu erityisyydessään, ja toteutuneessa esitystavassa on nähdäkseni kyetty käsitteellistämään kapitalismin erityisiä toteutumismuotoja, vaikkakaan ei ehkä aina riittävăn tarkasti. Vaikeuksia on vielä runsaasti ja varsinkin tavallaan näkymättömiä ongelmia, jotka liittyvät niin tutkimusainekseen kuin varsinaiseen tutkimustapaan. Tutkimusaineksen osalta on korostettava konkreettiseen ja empiiriseen aineistoon liittyviä pulmia, jotka kytkeytyvät niin tietoperustan puuttumiseen - varsinkin pitkittäissarjat - aineistoa koskevien käsitemääritysten soveltumattomuuteen marxilaisen tutkimuksen kannalta ja myös siihen suoranaiseen manipulointiin, jota porvarillinen tiedontuotanto toteuttaa. Näissä kysymyksissä emme ole useinkaan kyenneet saavuttamaan koherenttia ratkaisua.

Tutkimustavan se puoli, joka paremminkin riippuu itse tutkijoista kuin empiirinen aineistopuoli, saattaa itsekriittisessä katsannossa olla todellinen Akhilleen kantapää. Tarkoitan niitä spesifejä konkreettisen tutkimuksen konkreettisia metodeja, konkreettista dialektiikkaa, joiden 
avulla tuloksiin on päädytty. Joskaan tutkimuksessa ei ole "valistuneesti"' käytetty yhteiskuntatieteen uusimpia tutkimustekniikkoja ja -metodiikkoja, se on ollut tietoinen valinta, joka perustuu harkintaan muttei riittävään keskusteluun. Sen sijaan on kyllä problematisoitu ja käytetty sellaisia konkreettisen kohteen "hajottamisen dialektiikan" ajatusvälineitä kuten aineiston jaottelua ja jaksottelua eli periodisointia, jotka perinteisesti kuuluvat marxilaisen konkreettisen tutkimuksen arsenaaliin.

Kun kirja on näinkin laajan valmistelun tulos, olisi mielenkiintoista kuulla jotakin itse valmistelusta, työprosessista. Mistä se sai alkunsa?

Antti Kasvio: Henkilökohtaisesti en muista aivan tarkkaan kaikkia Valtiomonopolistinen kapitalismi Suomessa -projektin alkuun liittyviä yksityiskohtia. Joka tapauksessa lähinnä sosialistisen opiskelijaliikkeen piirissä koettiin 1970-luvun alussa kipeänä tarve suomalaisen kapitalismin uusien piirteiden erittelyyn marxilaisen yhteiskuntateorian pohjalta. Vasta perustetun Sosialistisen opintoneuvonta- ja tutkimuskeskuksen toimesta perustettiin vuoden 1972 alussa projektiryhmä, jonka tehtävänä oli kokonaisanalyysin tuottaminen Suomen valtiomonopolistisesta kapitalismista.

Aivan työn alkuvaiheessa Soihtu julkaisi laajahkon artikkelini Valtiomonopolistinen kapitalismi Suomessa: aineistoa tutkimustyötä varten (Soihtu 4/72), joka auttoi ehkä osaltaan jäsentämään tutkimustyötä eteenpäin. Sosialistisen opiskelijaliikkeen ja nuoren tutkijakunnan keskuudessa projekti herätti runsaasti mielenkiintoa, ja työtä jatkettiinkin eteenpäin eri lohkoihin jakautuneissa työryhmissä. Paljolti oli kysymys siitä, että opiskelijat halusivat kytkeä pro gradu -työnsä tai muut opintonsa projektin työskentelyyn.

Tavallaan uutta vaihetta työn etenemisessä merkitsi tutkimuksen teoreettis-metodologisista lähtökohdista käyty keskustelu, jota hyvin edustaa Pekka Kososen, Timo Kyntäjän ja Raimo Lovion kirjoittama tutkielma "Valtiomonopolistisen kapitalismin teorian perusteista". Samalla kun tämä keskustelu nosti esille mm. kysymykset sisäisten ja ulkoisten tekijöiden keskinäissuhteesta valtiomonopolistisen kapitalismin kehityksessä ja pääoman arvonlisäysristiriitojen analyysin välttämättömyyden, se oli omiaan vapauttamaan projektin työskentelyä liian tiukasta jakautumisesta lohkoihin, joka oli tunnusomaista projektin alkuvaiheelle. Tämän jälkeen oli projektin johto ja eri tutkimusryhmät, joiden yhteistyötä pyrittiin edistämään.

\section{Nyt, kun kirja on valmis, voi kai arvioida projektin ja kirjoitustyön kokemuksia.}

Pekka Kosonen: Ainakin kokemuksia on tällaisen laajan projektin työstä kyllä kertynyt. Siinähän toimi jatkuvasti monia enemmän tai vähemmän säännöllisiä tutkimusryhmiä, joilla oli rajatut aiheensa (esimerkiksi Suomi ja maailmantalous). Järjestettiin monia seminaareja ja palavereja, tuloksia julkaistiin lehdissä ja omissa sarjoissa. Opiskelijoilla oli ilmeistä tarvetta kytkeä omaa työtä mielekkääseen aiheeseen. Näin laajasti toimivana projekti lakkasi joskus vuoden $\mathbf{- 7 5}$ lopussa ja -76 alussa, mutta sen kokemuksista kannattaa yhä keskustella. Tutkimusryhmät toimivat hyvin vaihtelevasti, osa sai aikaan tärkeää perusanalyysia, osalla työ jäi keskustelun ja opiskelun asteelle. Työtä arvioitaessa on huomattava, että se perustui vapaaehtoisuuteen eikä aineellisia resursseja ollut käytössä. Tämähän vaikuttaa mahdollisuuksiin kerätä aineistoja, julkaista tuotteitaan jne. Myös kokemattomuus tăllaiseen työskentelyyn verotti tuloksia: teoreettinen pohja oli varsinkin alussa heikko eikă tutkimusryhmien ja koko projektin vastaavilla ollut kokemusta työn ohjauksessa. Projektin vetämistä hankaloitti tietysti vielä sen laajuus, kun siihen periaatteessa kuului toistakymmentä tutkimusryhmää. 
Mutta hankaluuksien vastapainoksi vaakakuppiin jää tärkeitä kokemuksia. Ensinnäkin yksittäisten tutkijoiden tavallaan perustavan työn ohella ja tälle olennaisesti rakentuvana tarvitaan nähdäkseni edelleen myös joitakin tutkimusprojekteja selvittämään tärkeiltä tuntuvia asioita. Näiden on kuitenkin oltava tätä vamokap-projektia suppeampia ja kytkeydyttävä suoraan tutkijoiden omiin intresseihin. Projektit eivät kuitenkaan voi koskea läheskään kaikkia marxilaisia tutkijoita. Mutta, toiseksi, läheistä aihetta tutkivien yhteinen keskustelu ja kritiikki on jatkuvasti tarpeen tulosten saavuttamiseksi ja välittämiseksi.

Itse Suomalainen kapitalismi -kirjan kirjoittaminen on myös ollut vivahteikas prosessi. Kirjaa tehtiin pari-kolme vuotta. Eri lukuja jaettiin yksittäisille tutkijoille, mutta koska esityksestä haluttiin yhtenäinen, suunnitelmaa kehiteltiin myös yhdessä. Tässäkin resurssien puute ja muut vaikeudet vaikuttivat niin, että minulle vastaavana kirjoittajana jäi varsin suuri osa tekstistä harteilleni. Kollektiivinen työ on siis toisaalta vaativaa, mutta mahdollistaa erilaisten kokemusten keräämisen ja voi onnistuessaan näkyä lopputuloksen monipuolisuudessa.

Kari Toikka: Haluaisin kommentoida kysymystä projektimuodosta, joka on mielestäni meidän marxilaisen tutkimuksemme eräs organisatorinen ydinkysymys. Minulla on sellainen käsitys, että tämän kirjan osalta projektimuoto toteutui varsin itumaisena. Tarkoitan projektityöskentelyllä tutkijoiden yksityistöiden kytkemistä yhteistoiminnalliseen tutkimusorganisaatioon, yhteisen päämäärän saavuttamiseksi. Ilmeisesti suurimmalle osalle kirjan parissa työskentely oli lähinnä sivutyö tai vapaa-ajan harrastus.

Tästä on mahdollista vetää kaksi johtopäätöstä. Ensimmäinen näyttää välittömästi realistiselta, mutta irrallisena se saattaa jäädä pinnalliseksi. Voitaisiin näet ajatella, että jatkossa olisi ylipäänsä aihetta suurempaan nöyryyteen ja vaatimattomuuteen, tulisi tyytyä yksityistutkimukseen tai rajoitettuihin projekteihin.

Toinen, mielestäni parempi johtopäätös, on pyrkimys projektityön syventämiseen. Tutkimuksen yhteiskunnallistuminen on sen tieteellisen ja poliittisen relevanssin, tuottavuuden ym. yhä välttämättömämpi ehto. Erityisesti tämä pätee marxilaisen tutkimuksen suhteen Suomen nykyisessä tiedepoliittisessa tilanteessa. Tämä on iso prosessi. Eräänä sen ehtona on pienen tavaratuottajan mentaliteetin ylittäminen, ts. sen käsittäminen, että tutkimus ei ole satunnaisiin yksilökohtaisiin intresseihin ja mieltymyksiin kokonaan palautuvaa toimintaa - korkeintaan palkkasuhteen ja tieteellisen ilmapiirin pakkojen välittämänä. Tällainen käsitys saattaa istua enemmän tai vähemmän tiukasti omissa päissämmekin. Toisena ehtona on $\mathrm{mm}$. sellaisen reaalisen tutkimuspotentiaalin kehittyminen, johon todella kannattaa olla yhteydessä, johon voi nojata omassa henkilökohtaisessa kehityksessään ja jonka yhteydessä oman panoksen merkitys todella kasvaa.

Pitäisi siis suuntautua todellisiin - nykyoloissa ehkä useimmiten välttämättä rajoitettuihin projekteihin. Mutta nämä olisi nähtävä kehitysaskelina syvempään ja pysyvämpään marxilaisen tutkimuksen yhteiskunnallistamiseen.

Voitteko lopuksi tehdä yhteenvetoa suomalaisen kapitalismin tutkimuksen tilasta. Missä kysymyksissä on edetty, missä suunnassa tutkimusta on tarpeen erityisesti syventää?

Pekka Kosonen: Varsin useissa kysymyksissä on 70-luvun mittaan edetty - konkreettista kapitalismitutkimustahan on suoritettu muuallakin kuin projektissamme tai Suomalainen kapitalismi -kirjaan liittyen - ja eräissä kysymyksissä välituloksia voi pitää vähemmän alustavina kuin toisissa. Esimerkiksi pääoman uusintamisen luonnetta koskevat analyysit ovat kiteytyneet tiettyyn näkemykseen, samoin valtion puuttuminen pää- 
oman uusintamiseen on pääpiirteissään hahmotettu. Suomen tuotannon kansainvälisistä suhteista on olemassa yleiskuva, joka osoittaa selvät erot suhteissa kapitalistisiin ja sosialistisiin maihin. Myös työvoiman uusintaminen on jäsennetty aiempaa selvemmin. Toisaalta monista työvoiman uusintamisen osakysymyksistä kaivataan edelleen aivan perustietoa, samalla kun aiheen teoreettisessa analyysissakin on tehtävää. Suomalaisen kapitalismin historiaa ei ole laajasti tutkittu, ja kirjassa aiheesta on vain yleinen tiivistys esityksen taustaksi. Poliittisen järjestelmän tutkimisen kipeään tarpeeseen ovat Sakari Hänninen ja Kari Toikka jo aiemmin viitanneet. Ja kun 70-luvun alkupuolella varmaan oikein todettiin luokka-analyysin olevan yhteiskunnan kokonaisanalyysia, nyt kokonaisanalyysien jälkeen voitaneen uudelleen pohtia tarkemmin luokkarakenteen ja luokkasuhteiden erityiskysymyksiä. Erittäin suppeaksi Suomessa on jäänyt tutkimus, jota voi kutsua ideologisten prosessien tai yhteiskunnan tajunnallisen uusintamisen tutkimiseksi. Tässä näen tärkeänä asiana, mitä myös kirjamme lyhyessä ideologisia prosesseja käsittelevässä luvussa halutaan korostaa, että tutkitaan laajasti tietoisuuden muotoutumista eikä vain manipulaatiota tai poliittis-ideologista taistelua.

Pääoman uusintamisen viimeaikaiset muutokset ja kriisi asettavat myös keskeiseksi tehtäväksi esimerkiksi investointien luonteen, automaation, kansainvälisen työnjaon rakenteen muutoksen ja näihin kytkeytyvien vakavien työttömyysongelmien analyysin.

Lisäksi haluan korostaa välttämättömyyttä haaroittaa marxilaista yhteiskuntatutkimusta. Aivan toisenlaisiakin tutkimuksia kuin mitä sisältyy Suomalainen kapitalismi -kirjaan kaivataan. Viime vuosina onkin vilkastunut ihmisten elämäntavan tai yleensä arkielämän tutkiminen. Esimerkiksi sivistyneistön sekä materiaalisen että henkisen aseman analyysi on tärkeää, ja myös se tuntuu olevan 'tulossa'". Aiheiden ja näkökulmien osalta moninaisuus on nähdäkseni hyvä, mutta samalla tietty kytkentä kapitalismin perusanalyysiin on tarpeen.

Sakari Hänninen: Yhdyn siihen korostukseen, ettei ole mitään yhtä ja oikeata tapaa tehdä konkreettista marxilaista tutkimusta. On monia mahdollisuuksia, jotka ulottuvat teoriareduktiivisesta reaalianalyysista reportaasityyppiseen toimintaanalyysiin ... Suomalainen kapitalismi -kirjan konkreettis-yleinen ja konkreettis-erityinen analyysi on tarkastelutasoltaan näiden ääripäiden välimaastossa sulkematta kuitenkaan esityksestä sen paremmin kapitalismin yleisimpien muotojen tunnistamista kuin mitä historiallisimpien muotojen illustrointia. On luonnollista, että kirjan painotus sulkee tarkastelusta monta konkreettista erittelyä kaipaavaa kohdetta, jotka edellyttävät olennaisesti toisentyyppistä tutkimusstrategiaa. Tällaisiin esimerkkeihin, kuten arkielämän ongelmiin on jo edellä viitattu. Kirjan rajaukset eivät tarkoita sitä, etteikő konkreettinen kapitalismianalyysi voisi periaatteessa yhdistää erilaisten tutkimusstrategioiden tuloksia. Tavoitteena on hyvä pitää tarkastelutasoltaan, historialliselta käypyydeltään ja tutkimuskohteiltaan mahdollisimman monipuolista analyysia, ainakin silloin kun kyseessä on kirjan tavoin laaja systematisoiva synteesi.

Mitä erilaisimmat tutkimuksen osa-alueet voivat kukin sijoittua eri tarkastelutasoille yleisyytensä ja historiallisen pysyvyytensä suhteen. Tilannetta voi valaista valtion ja politiikan osalta. Suomalainen kapitalismi -kirjassa poliittisen järjestelmän organisoitumismuodon sisällä tarkastellaan sekä puolidemokraattista että parlamentaaris-demokraattista hallitsemistapaa; tätä astetta historiallisempi ja konkreettisempi kategoria on hallitustyyppi. Kirjassa toteutettu konkreettisyleinen ja konkreettis-erityinen analyysi nähdäkseni painottuu hallitsemistavan ja hallitustyyppien historisoivaan erittelyyn, jota tukee valtiokoneiston institutionaalinen ja rakenteellinen tarkastelu. Kokonaisnäkemys on uutta luova suo- 
malaisessa politiikan tutkimuksessa, mutta valtion ja poliittisen käytännön analyysi kaipaa runsaasti jatkotutkimusta jo tärkeytensä takia. Vähäisin syy ei ole se, että establishoitunut politiikan tutkimus on miltei poikkeuksetta laiminlyönyt niin koko poliittisen järjestelmän kuin poliittisten voimien ja prosessien selvityksen. Ei ole olemassa erillistutkimuksia, joiden tuloksia voidaan kriittisesti hyödyntää. Kaikkein vakavim- pana puutteena näkisin ne aukot, jotka liittyvät yhteiskunnallisten joukkoliikkeiden, poliittisten puolueiden, etujärjestöjen ja esikuntien kuin myös poliittista hegemoniaa ja legitimaatiota ylläpitävien prosessien tutkimukseen. Ilman tällaisten luokkataistelukäytäntöä ja valtion konkreettista toimintatapaa välittävien voimien ja prosessien konkreettis-erityistä selvitystä on vaikea syväluodata suomalaisen politiikan koko kuvaa.
HOMO SAPIENS johdatus biologiseen ihmiskuvaan

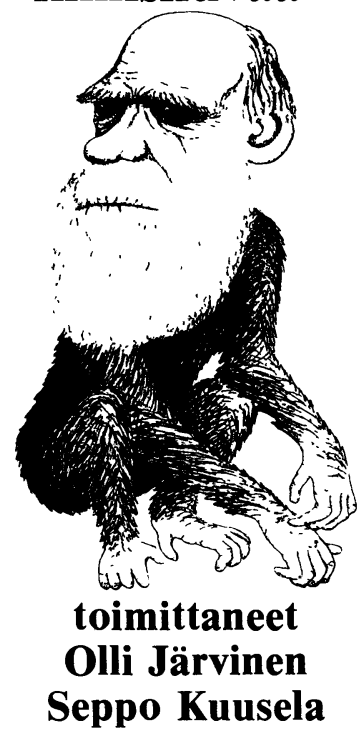

Symbioosi \& Tutkijaliitto

\section{HOMO SAPIENS}

- johdatus biologiseen ihmiskuvaan. Toimittaneet Olli Järvinen, Seppo Kuusela.

Selkeä johdatus biologiseen ihmiskuvaan. Tarkoitettu biologiaa harrastaville, mutta myös luonnontieteen, lääketieteen, käyttäytymistieteiden ja yhteiskuntatieteiden tutkijoille, opettajille, opiskelijoille, toimittajille jne.

',Johdatus biologiseen ihmiskuvaan on virkistävä ja jännittävä kirja. . .Erityisesti biologista tietoa työkseen jakavien kannattaisi kirjan avulla ravistella opiskeluaikaisia pinttymiä ja tarkastella omaa biologismiaan kriittisin mielin." (Matti Leinonen, HS 22. 7. 1979).

Sisällys (184 sivua): Kurtén: Ihmisen biologinen kehitys, Voipio: Ihmisen rakenteellisista erikoispiirteistä. Järvinen: Ihmisrotujen ja ihmisen älykkyyden biologiasta. Saura: Theodosius Dobzhanskyn biologia ja ihmiskäsitys. Grönholm, Salemaa, Sutela: Kolme biologistista ihmiskäsitystä (Lorenz, Morris, Ardrey). Vepsäläinen: Ihmisen sosiobiologia. Haila: Biologismi ja tieteellinen ihmiskuva. Aro, Pakaslahti: Sairas ihminen - luonnontieteen vai yhteiskuntatieteen potilas? Järvilehto: Voidaanko psyykkinen toiminta palauttaa hermoston toimintaan? Sarmela: Kulttuuriantropologia ihmistutkimuksen välineenä. Kuusela: Ihmisen ekologia - uusi biotiede? Massa: Ekologinen antropologia. Kirjaa myyvät hyvin varustetut kirjakaupat. Edullisinta on tilata kirja suoraan Tutkijaliitosta. Maksa 42 mk ps-tilillemme 5533 21-3 (Tutkijaliitto, Vuorikatu 8 A 3, Hki 10), niin lähetämme kirjan kotiisi välittömästi ilman lisäveloituksia. Tiedustelut: Tutkijaliitto, P. 90-633239. 